\title{
EFFECTS OF ACUTE INCREASES IN THE EXCRETION OF SOLUTE AND WATER ON RENAL ACID EXCRETION IN MAN *
}

\author{
By PHILIP R. STEINMETZ † AND NORMAN BANK $\ddagger$ \\ (From the Department of Medicine, New York University School of Medicine, \\ Now York, N.Y.)
}

(Submitted for publication August 1, 1962 ; accepted March 21, 1963)

It is well established that renal acid excretion can be influenced by certain tubular mechanisms that operate independently of systemic acid-base equilibrium. Thus, the stimulus for sodium reabsorption $(1,2)$, the competition between potassium and hydrogen ions for secretion (3), and the penetrating ability of anions present in the glomerular filtrate (4-6) are factors known to affect acid excretion. It is not clear, however, whether the process of urine acidification is influenced by the quantities of solute and water being excreted by the kidney. Although acid excretion has been measured during various types of diuresis (7-11), most studies were not specifically designed to answer this question.

In the present study, the effects of acute increases in either solute or water excretion on the simultaneous excretion of acid were examined in man. To investigate the effects of solute and water separately, water excretion was limited as much as possible during solute diuresis, and changes in solute excretion were avoided during water diuresis. Control observations on acid excretion were made in nondiuretic subjects in the recumbent position.

The results indicate that diuresis induced by nonelectrolyte solutes (hypertonic urea or mannitol) causes a significant fall in urine $\mathrm{pH}$ and an increase in ammonium and titratable acid excretion in recumbent subjects. In contrast, water diuresis had no consistent effect on over-all acid ex-

* Supported by grants $\mathrm{H}-5770$ and $\mathrm{H}-4076$ from the National Heart Institute, Bethesda, Md.; the Life Insurance Medical Research Fund; and grant U-1045 from the Health Research Council of the City of New York. Presented in part before the Eastern Section Meeting of the American Federation for Clinical Research, Baltimore, Md., December 14, 1962.

$\dagger$ Postdoctoral Research Fellow, U. S. Public Health Service.

$\$$ Career Scientist, Health Research Council of the City of New York. cretion, even though urine $\mathrm{pH}$ rose in upright subjects elaborating an acid urine. These observations suggest that the rate at which solute is excreted may be a determinant of renal acid excretion in man.

\section{METHODS}

Nineteen experiments were carried out in thirteen normal subjects. In order to ensure a comparable state of hydropenia, no food or fluid was taken for 12 to 14 hours before each study. The effects of solute diuresis were studied in eight series of observations on six subjects. Control urine collections were begun approximately $30 \mathrm{~min}$ utes after the subject had assumed the recumbent position and had received $10 \mathrm{U}$ of aqueous vasopressin 1 intramuscularly. After the control periods, either $20 \%$ mannitol in water or $15 \%$ urea in isotonic dextrose was infused intravenously at a rate of 3 to $5 \mathrm{ml}$ per minute. In addition, $200 \mathrm{mU}$ of vasopressin was administered per hour with the infused fluid. In three subjects receiving im vasopressin, control observations were made on the effects of recumbency alone without administration of solute.

The effects of water diuresis on acid excretion were studied in eight series of observations. In four subjects in the recumbent position, water diuresis was induced by iv infusion of $3 \%$ dextrose solution at a rate of 6 to 10 $\mathrm{ml}$ per minute and by ingestion of approximately $1 \mathrm{~L}$ of water. In four other experiments, diuresis was induced by ingestion of about $1,500 \mathrm{ml}$ of water while the subjects remained in an upright position, i.e., standing, walking about, or seated on a high stool. All experiments were carried out between 8:00 a.m. and 1:00 p.m. Urine was collected under mineral oil by bladder catheter in nine subjects and by spontaneous voiding into graduated cylinders containing mineral oil in the remaining subjects. From two to six venous blood specimens were collected into heparinized syringes during the course of each experiment, and samples were placed under oil for $\mathrm{pH}$ and $\mathrm{CO}_{2}$ determination. Glomerular filtration rate was measured by either inulin or endogenous creatinine clearance $(12,13)$. The osmolality of plasma and urine was determined with a Fiske osmometer within 3 hours after completion of each study. Urine sodium and potassium were measured by flame photometry with lithium as an internal standard,

1 Pitressin, lot no. W107GA, Parke, Davis \& Co., Detroit, Mich. 


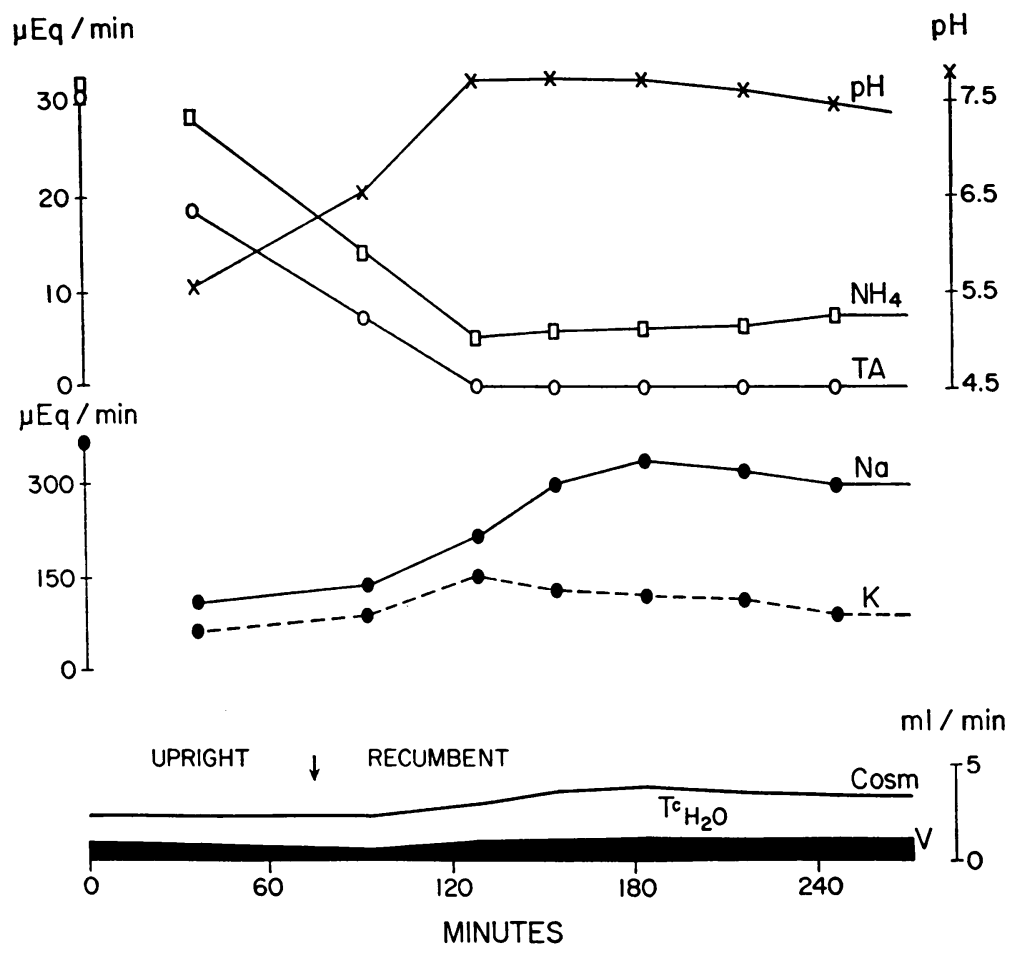

Fig. 1. EfFects of ASSUMing the ReCumbent position on ACID AND SOLUTE EXCRETION. The subject had been ambulatory for 2 hours before urine collections were begun. $\mathrm{TA}=$ titratable acid; $\mathrm{C}_{\text {osm }}=$ osmolar clearance; $\mathrm{T}_{\mathrm{H}_{2} \mathrm{O}}^{\mathrm{c}}=$ solute-free water reabsorption; $\mathrm{V}=$ rate of urine flow.

and chloride by the potentiometric method of Sanderson (14). Urine ammonium was determined by the method of Seligson and Seligson (15). Titratable acid was estimated by titrating undiluted samples of urine to the $\mathrm{pH}$ of blood with $0.1 \mathrm{~N}$ sodium hydroxide. The rate of urine flow (V) and all values derived from it were corrected for a surface area of $1.73 \mathrm{~m}^{2}$. Blood and urine $\mathrm{pH}$ were measured anaerobically at $37^{\circ} \mathrm{C}$ with a Metrohm model E322 pH-meter ${ }^{2}$ and capillary glass electrode. Plasma $\mathrm{CO}_{2}$ content was measured manometrically by the method of Van Slyke and Neill (16).

\section{RESULTS}

In Figure 1 the effects of recumbency without administration of solute or water are shown for one of three hydropenic subjects who were studied as controls. Assumption of the recumbent position resulted in a rise in urine $\mathrm{pH}$ and a decrease in titratable acid and ammonium excretion. The alkaluria reached a maximum after about $90 \mathrm{~min}$ utes and persisted thereafter with little change for more than 2 hours; it was accompanied by a sig-

\footnotetext{
2 Manufactured in Switzerland; U. S. distributor, Brinkmann Instruments, Inc., Great Neck, N. Y.
}

nificant natriuresis. The results of the other two experiments (see Figure 3) were similar in that urine $\mathrm{pH}$ rose to values above 7.0 and remained at that level for 3 hours, as long as observations were continued. These findings are in complete agreement with previous studies by Thomas (17).

The results of diuresis induced by nonelectrolyte solutes in recumbent subjects are presented in Figures 2 and 3 and in Table $I$. In Figure 2, the changes in acid excretion with urea diuresis (A, B, and C) and with mannitol diuresis $(\mathrm{D}, \mathrm{E}$, and $\mathrm{F})$ are shown for six of the eight experiments. The osmolar clearance $\left(\mathrm{C}_{\mathrm{osm}}\right)$ increased from control values of 1 to $4 \mathrm{ml}$ per minute to diuretic values of 7 to 15 $\mathrm{ml}$ per minute. Significant quantities of solute-free water $\left(\mathrm{T}_{\mathrm{H}_{2} \mathrm{O}}^{\mathrm{c}}=\mathrm{C}_{\mathrm{osm}}-\mathrm{V}\right)$ were reabsorbed, consistent with maximal antidiuretic hormone (ADH) activity. With onset of solute diuresis, the alkaluria of recumbency was interrupted, urine $\mathrm{pH}$ fell, and ammonium and titratable acid excretion increased. The effects were slightly greater with mannitol than with urea, as was the magnitude of 

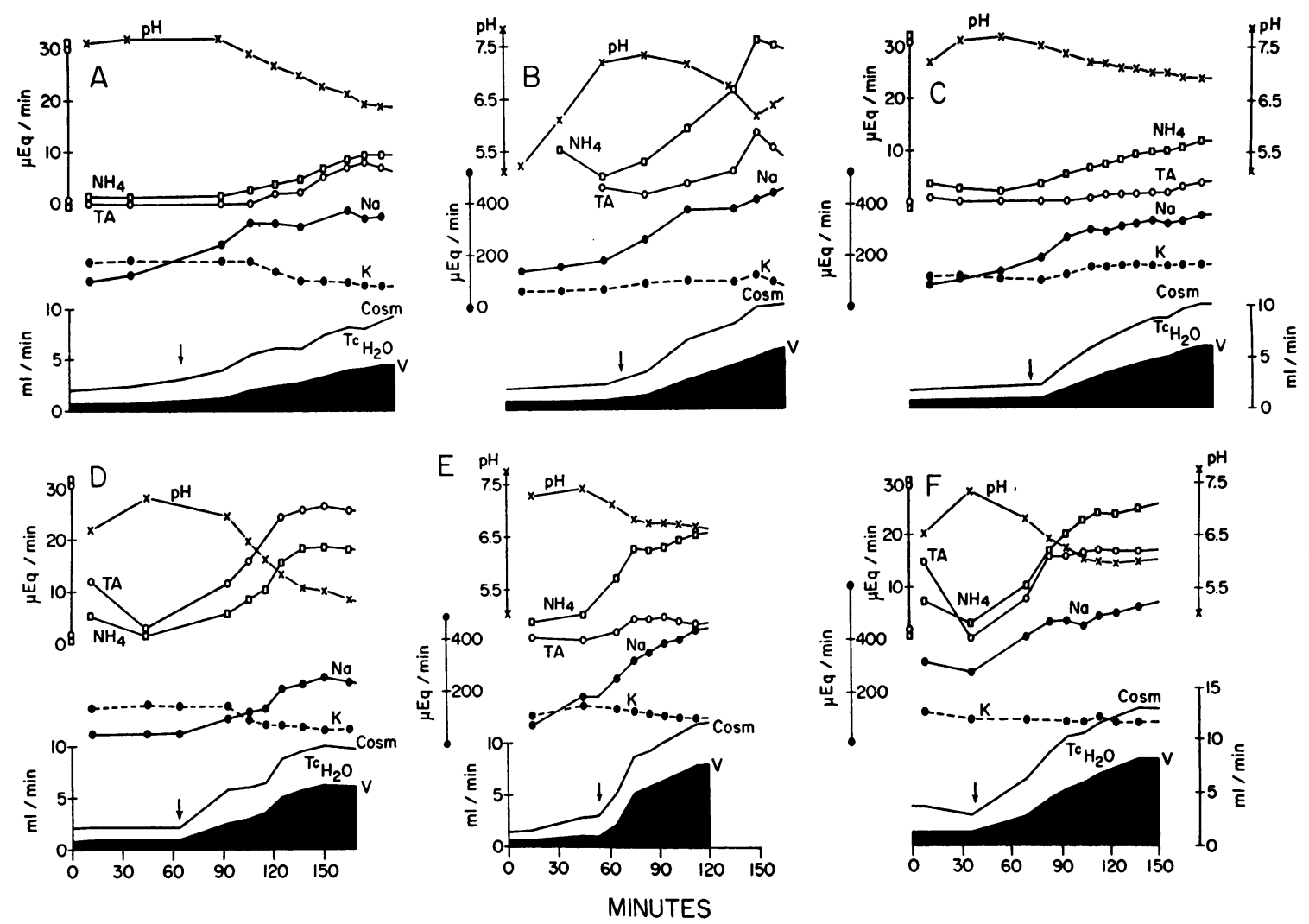

Fig. 2. Renal acid excretion during uRea and mannitol diUResis in recumbent subjects. Diuresis was in duced with hypertonic urea in $\mathrm{A}, \mathrm{B}$, and $\mathrm{C}$ and with hypertonic mannitol in $\mathrm{D}, \mathrm{E}$, and $\mathrm{F}$. The arrows indicate the beginning of the infusion. $\mathrm{TA}=$ titratable acid; $\mathrm{C}_{\mathbf{~ o s m}}=$ osmolar clearance; $\mathrm{T}^{\mathrm{c}} \mathbf{H}_{20}=$ solute-free water reabsorption; $\mathrm{V}=$ rate of urine flow.

diuresis. Sodium excretion averaged $136 \mu \mathrm{Eq}$ per minute during the last prediuretic period (range, from 25 to $272 \mu \mathrm{Eq}$ per minute) and increased to an average value of $386 \mu \mathrm{Eq}$ per minute. Changes in potassium excretion were inconsistent. In Table $\mathrm{I}$, experiments $\mathrm{D}$ and $\mathrm{E}$ are shown in further detail. In Figure 3, the results in all eight studies on the effects of solute diuresis are presented in the form of a delta plot. The last prediuretic period, chosen arbitrarily as the zero point, is compared with from two to four periods at the height of solute diuresis. The solid lines and closed circles represent the three series of observations on the effects of recumbency by itself. The collection period approximately 100 minutes after the recumbent position had been assumed was taken as the zero point, since a similar period of decumbency preceded solute infusion in the studies on osmotic diuresis. Solute diuresis resulted in a fall in urine
$\mathrm{pH}$ of approximately $1 \mathrm{U}$ and in average increases in titratable acid and ammonium excretion of 9 and $16 \mu \mathrm{Eq}$ per minute, respectively. These changes are in contrast to the constancy of acid excretion during recumbency alone.

The effects of water diuresis on urine $\mathrm{pH}$ and acid excretion are shown in Figures 4 and 5 and in Table II. In Figure 4, one of four studies carried out in recumbent subjects is presented. As expected in the recumbent position, urine $\mathrm{pH}$ was in the alkaline range before the diuresis, and ammonium and titratable acid excretion rates were low. With onset of water diuresis, urine $\mathrm{pH}$ fell slightly, but ammonium and titratable acid excretion did not change. Free-water clearance $\left(\mathrm{C}_{\mathrm{H}_{2} \mathrm{O}}\right)$ increased to about $10 \mathrm{ml}$ per minute, and $\mathrm{C}_{\text {osm }}$ remained relatively constant. The other studies in recumbent subjects were similar except that in one subject a slight aciduria occurred with increases in 
ammonium and titratable acid excretion (see Table II). In Figure 5, two experiments carried out in subjects in the upright position are shown. The control urine was in the acid range, as would be expected in the upright position (see Figure 1). Water diuresis resulted in a relative alkaluria, urine $\mathrm{pH}$ rising about $1.0 \mathrm{U}$, without significant change in ammonium or titratable acid excretion. Small increases in the excretion of potassium, sodium, and chloride also occurred.

The eight experiments on water diuresis are summarized in Table II. The average values at the height of diuresis are compared with the mean of the last two or three control periods.

Blood $\mathrm{pH}$ and $\mathrm{CO}_{2}$ content, measured during the control and diuretic periods, were within the normal range in all subjects and no consistent changes occurred with either solute or water loading. Simi-
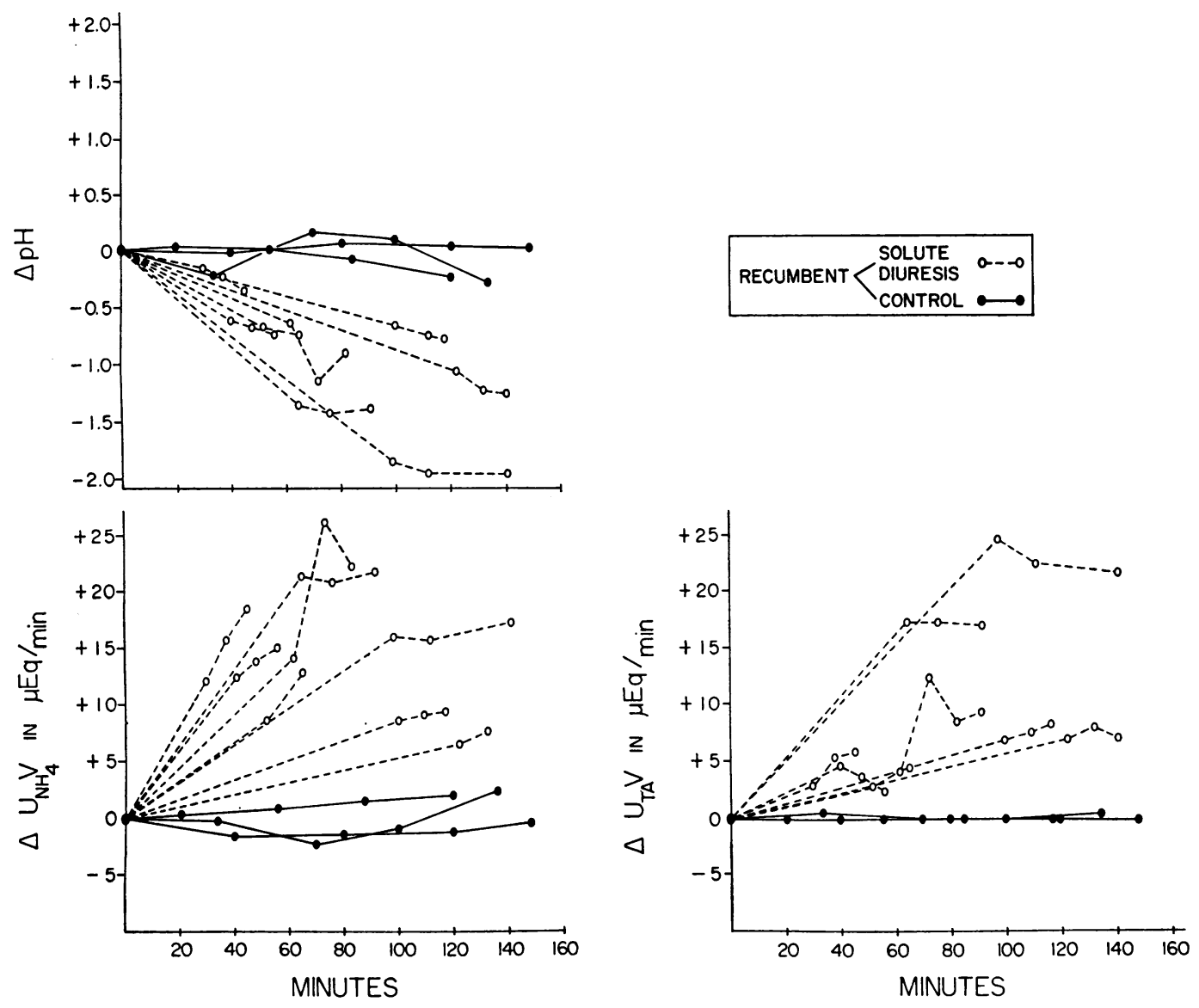

Fig. 3. Comparison of Changes in URine pH, ammonium, and titratable acid (TA) excretion DURING SOLUTE DIURESIS AND RECUMBENCY ALONE. The collection period approximately 100 minutes after the recumbent position had been assumed was taken as the zero point in both groups of experiments. larly, glomerular filtration rate did not show any consistent trend.

\section{DISCUSSION}

These studies demonstrate that the effect of water diuresis on urine $\mathrm{pH}$ is dependent upon the $\mathrm{pH}$ value before diuresis. Thus, in subjects in the recumbent position excreting an alkaline urine, little or no change was observed, whereas in standing subjects elaborating an acid urine, a relative alkaluria resulted. Barclay, Cooke, Kenney, and Nutt (7) similarly reported that the response to water diuresis depends on the $\mathrm{pH}$ of the control urine, although in their study prediuretic $\mathrm{pH}$ was varied by means other than posture. Nutbourne and de Wardener (11) studied water diuresis in seated subjects who had received ammonium chloride and observed a rise in urine $\mathrm{pH}$ comparable to that

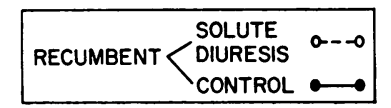


TABLE I

The effect of mannitol diuresis on acid excretion in two recumbent subjects*

\begin{tabular}{|c|c|c|c|c|c|c|c|c|c|c|c|c|c|}
\hline \multirow[b]{2}{*}{ Time } & \multicolumn{9}{|c|}{ Urine } & \multirow[b]{2}{*}{$\mathrm{C}_{\mathrm{cr}}$} & \multicolumn{3}{|c|}{ Plasma } \\
\hline & Flow & Uosm & Cosm & $\mathrm{Na}$ & $\mathbf{K}$ & $\mathrm{Cl}$ & $\mathrm{NH}_{4}$ & TA & $\mathrm{pH}$ & & $\mathrm{pH}$ & $\mathrm{HCO}_{3}$ & $\mathrm{pCO}_{2}$ \\
\hline $\min$ & $\min _{\min }$ & $\underset{k g}{m O s m / ~}$ & $\begin{array}{l}m l / \\
m i n\end{array}$ & $\underset{\min }{\mu E q /}$ & $\underset{\min }{\mu E q /}$ & $\underset{\min }{\mu E q /}$ & $\underset{\min }{\mu E q /}$ & $\underset{\min }{\mu E q /}$ & & $\begin{array}{l}m l / \\
m i n\end{array}$ & & $\underset{L}{\text { mmoles/ }}$ & $m m \mathrm{Hg}$ \\
\hline \multicolumn{14}{|c|}{ Subject D } \\
\hline $\begin{array}{r}0-30 \\
30-60\end{array}$ & $\begin{array}{l}0.60 \\
0.55\end{array}$ & $\begin{array}{l}852 \\
890\end{array}$ & $\begin{array}{l}1.8 \\
1.7\end{array}$ & $\begin{array}{l}26 \\
25\end{array}$ & $\begin{array}{l}139 \\
149\end{array}$ & $\begin{array}{l}92 \\
68\end{array}$ & $\begin{array}{l}4.4 \\
1.8\end{array}$ & $\begin{array}{r}11.1 \\
1.9\end{array}$ & $\begin{array}{l}6.62 \\
7.26\end{array}$ & $\begin{array}{r}108 \\
96\end{array}$ & 7.43 & 24.1 & 38.4 \\
\hline 67 & \multicolumn{10}{|c|}{ Infusion : mannitol, $20 \%$ at $3.6 \mathrm{ml} / \mathrm{min}$} & & & \\
\hline $\begin{array}{r}87-100 \\
100-110 \\
110-120 \\
120-132 \\
132-145 \\
145-158 \\
158-173\end{array}$ & $\begin{array}{l}2.2 \\
2.7 \\
2.9 \\
4.6 \\
5.5 \\
6.0 \\
5.7\end{array}$ & $\begin{array}{l}\mathbf{6 9 2} \\
624 \\
589 \\
537 \\
501 \\
482 \\
483\end{array}$ & $\begin{array}{l}\mathbf{5 . 4} \\
\mathbf{5 . 7} \\
\mathbf{5 . 9} \\
\mathbf{8 . 5} \\
9.3 \\
9.7 \\
9.3\end{array}$ & $\begin{array}{r}98 \\
117 \\
134 \\
208 \\
229 \\
257 \\
236\end{array}$ & $\begin{array}{r}147 \\
85 \\
64 \\
64 \\
54 \\
48 \\
46\end{array}$ & $\begin{array}{l}143 \\
148 \\
155 \\
226 \\
256 \\
287 \\
258\end{array}$ & \begin{tabular}{r|}
5.0 \\
7.7 \\
9.4 \\
14.6 \\
18.0 \\
17.7 \\
16.8
\end{tabular} & $\begin{array}{l}10.7 \\
15.2 \\
16.9 \\
24.0 \\
25.6 \\
26.3 \\
24.1\end{array}$ & $\begin{array}{l}6.87 \\
6.38 \\
6.03 \\
5.70 \\
5.46 \\
\mathbf{5 . 4 0} \\
\mathbf{5 . 2 8}\end{array}$ & $\begin{array}{r}126 \\
101 \\
86 \\
100 \\
99 \\
93 \\
89\end{array}$ & $\begin{array}{l}7.40 \\
7.41\end{array}$ & $\begin{array}{l}23.6 \\
24.7\end{array}$ & $\begin{array}{l}39.3 \\
40.2\end{array}$ \\
\hline \multicolumn{14}{|c|}{ Subject E } \\
\hline $\begin{array}{r}0-26 \\
26-52\end{array}$ & $\begin{array}{l}0.57 \\
1.2\end{array}$ & $\begin{array}{l}754 \\
732\end{array}$ & $\begin{array}{l}1.5 \\
3.0\end{array}$ & $\begin{array}{r}67 \\
183\end{array}$ & $\begin{array}{l}102 \\
151\end{array}$ & $\begin{array}{r}91 \\
179\end{array}$ & $\begin{array}{l}3.9 \\
5.5\end{array}$ & $\begin{array}{l}0.6 \\
0\end{array}$ & $\begin{array}{l}7.30 \\
7.41\end{array}$ & $\begin{array}{r}80 \\
122\end{array}$ & 7.40 & 26.0 & 43.3 \\
\hline 54 & \multicolumn{10}{|c|}{ Infusion : mannitol, $20 \%$ at $4.8 \mathrm{ml} / \mathrm{min}$} & & & \\
\hline $\begin{array}{c}52-70 \\
70-80 \\
80-90 \\
90-100 \\
100-110 \\
110-120\end{array}$ & $\begin{array}{l}2.4 \\
5.1 \\
5.7 \\
6.5 \\
7.2 \\
7.9\end{array}$ & $\begin{array}{l}587 \\
490 \\
467 \\
455 \\
443 \\
433\end{array}$ & $\begin{array}{r}5.1 \\
8.8 \\
9.3 \\
10.2 \\
11.0 \\
11.7\end{array}$ & $\begin{array}{l}258 \\
324 \\
354 \\
389 \\
402 \\
440\end{array}$ & $\begin{array}{r}132 \\
122 \\
114 \\
104 \\
100 \\
94\end{array}$ & $\begin{array}{l}266 \\
369 \\
384 \\
417 \\
428 \\
\mathbf{4 4 8}\end{array}$ & $\begin{array}{l}12.2 \\
17.9 \\
17.1 \\
18.1 \\
19.5 \\
20.6\end{array}$ & $\begin{array}{l}1.2 \\
4.1 \\
4.0 \\
4.5 \\
3.6 \\
2.4\end{array}$ & $\begin{array}{l}7.12 \\
6.77 \\
6.78 \\
6.78 \\
6.76 \\
6.71\end{array}$ & $\begin{array}{r}114 \\
104 \\
99 \\
98 \\
103 \\
101\end{array}$ & 7.41 & 26.1 & 42.5 \\
\hline
\end{tabular}

$* \mathrm{U}_{\mathrm{osm}}=$ urine osmolality; $\mathrm{C}_{\mathrm{osm}}=$ osmolar clearance; $\mathrm{TA}=$ titratable acid; $\mathrm{C}_{\mathrm{or}}=$ creatinine clearance.

found in our upright subjects. These authors further showed that the $\mathrm{pH}$ change cannot be reproduced in vitro by diluting the control urine to the osmolality of the diuretic urine, thus ruling out

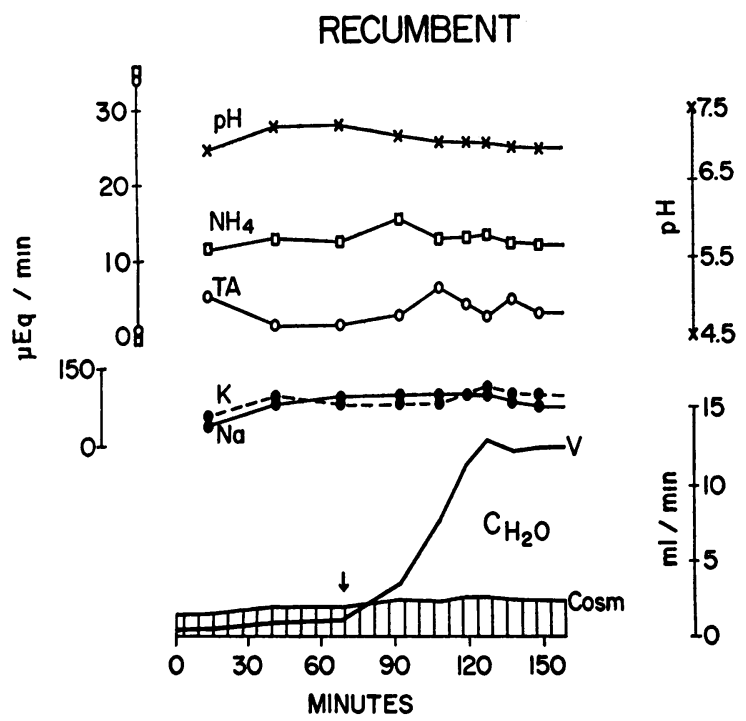

Fig. 4. RENAL ACID EXCRETION DURING WATER DIURESIS IN A RECUMBENT SUBJECT. The arrow indicates the beginning of infusion of $3 \%$ dextrose in water. $\mathrm{TA}=$ titratable acid; $\mathrm{V}=$ rate of urine flow; $\mathrm{C}_{\mathrm{H}_{2} \mathrm{O}}=$ free-water clearance; $\mathrm{C}_{\mathrm{osm}}=$ osmolar clearance. a purely physicochemical effect. The physiologic mechanism underlying this alkaluria, however, remains obscure. It is of interest that despite the $\mathrm{pH}$ rise, ammonium and titratable acid excretion did not decrease, as might have been expected (18). The tendency for ammonium excretion to decrease as urine $\mathrm{pH}$ rose may have been offset by the influence of increasing urine flow on the diffusion of $\mathrm{NH}_{3}$ into the urine, described by Orloff and Berliner (19). Whatever the mechanism, ammonium excretion during water diuresis appears to be relatively constant not only in the upright position, but also in the seated (11) and recumbent positions, irrespective of changes in urine $\mathrm{pH}$. Since titratable acid excretion likewise varied little in our subjects in either the recumbent or upright position, it can be concluded that acute increases in the excretion of solute-free water have little effect on over-all acid excretion.

In contrast to the observations on water diuresis and recumbency per se, solute diuresis induced by urea or mannitol resulted in consistent increases in acid excretion. Beck (10) and Eggleton (20) reported similar increases in acid excretion during diuresis induced by hypertonic mannitol and su- 


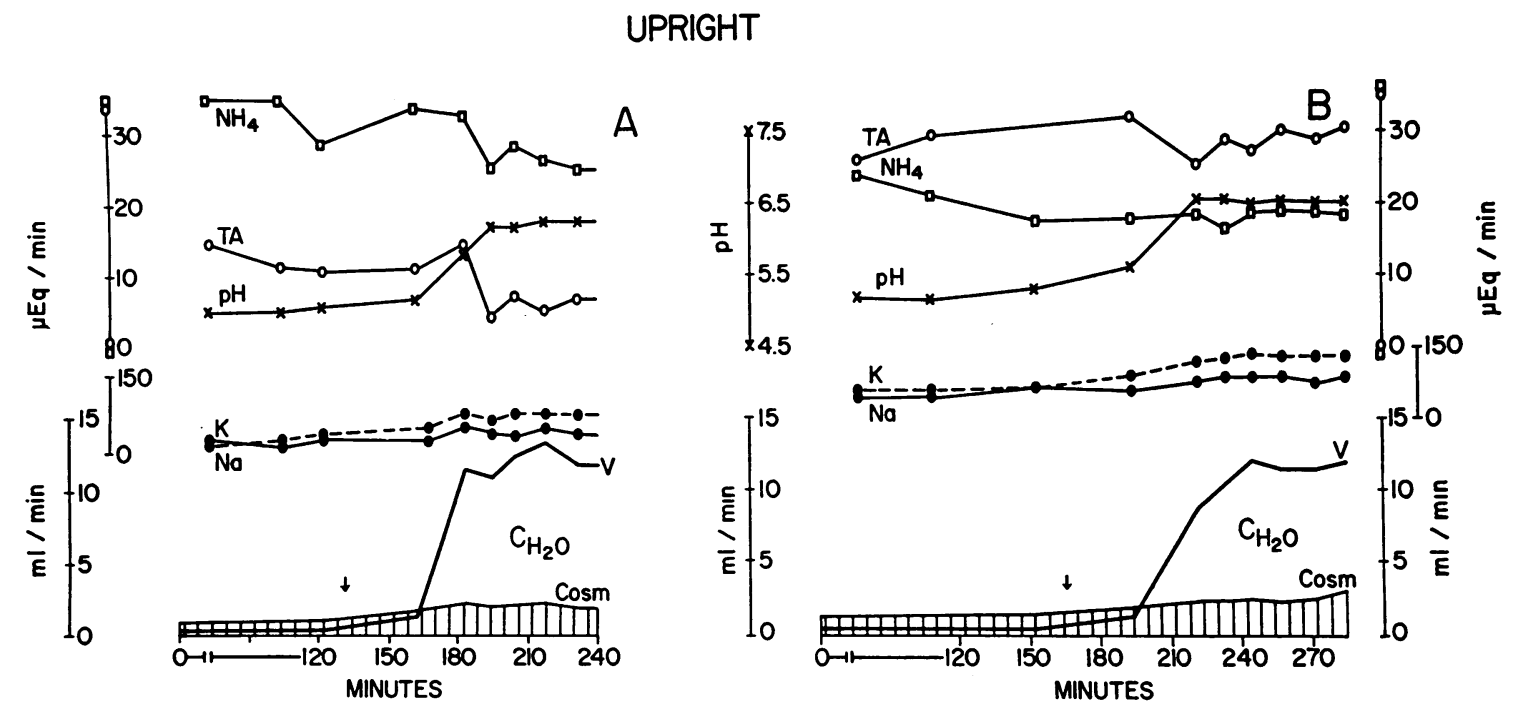

Fig. 5. RENAL ACID EXCRETION DURING WATER DIURESIS IN UPRIgHt sUbJeCts. The arrows indicate the time water ingestion was started. $\mathrm{TA}=$ titratable acid; $\mathrm{V}=$ rate of urine flow; $\mathrm{C}_{\mathrm{H}_{2} \mathrm{O}}=$ free-water clearance; $\mathrm{C}_{\mathrm{osm}}=$ osmolar clearance.

crose ${ }^{3}$ respectively. In the study of Beck (10), mannitol was administered more rapidly than in our experiments, and a rise in plasma $\mathrm{pCO}_{2}$ resulted to which the aciduria was attributed. In the present study, however, the increased acid excretion could not be accounted for by changes in systemic acidbase balance. Since glomerular filtration rate was little affected by solute infusion, it seems likely that the observed effect was determined at the tubular level.

Several tubular factors could have played a role in enhancing hydrogen ion excretion during osmotic diuresis. First, the rise in ammonium excretion might have been due to the effect of increased urine flow on the rate of nonionic diffusion (19). As discussed above, however, no consistent increases in ammonium excretion occurred with water diuresis despite considerably greater urine flow rates. Furthermore, an increase in urine flow in itself

\footnotetext{
${ }^{3}$ In contrast to the aciduria with hypertonic sucrose infusion, Eggleton (20) observed a relative alkaluria during diuresis induced by urea ingestion in well hydrated subjects. She suggested that the difference in response to these two solutes might be related to their ability to stimulate release of endogenous $\mathrm{ADH}$. The fact that acidification occurred during urea infusion in our hydropenic subjects receiving vasopressin supports this hypothesis. It is also possible, however, that ingestion of urea causes changes in systemic acid-base equilibrium.
}

could not explain the fall in urine $\mathrm{pH}$ or the rise in titratable acid excretion. Another explanation to be considered is that the sodium-hydrogen ion exchange mechanism was accelerated with increased delivery of sodium to the distal nephron. A third possibility is raised by recent micropuncture studies in the rat which have shown that the fluid in the proximal tubule is relatively acid in respect to plasma (21-23) and contains significant quantities of ammonium (24) and titratable acid (25). In the light of these data, it can be postulated that during osmotic diuresis in man increased quantities of relatively acid proximal fluid are delivered to the distal nephron and that ammonium and titratable acid formed in proximal segments of the nephron reach the final urine. Since the alkaluria of the control periods was associated with a significant natriuresis in six of the eight experiments, it seems likely that distal sodium-hydrogen ion exchange was depressed as a result of recumbency and that sodium was being rejected by the exchange sites. The effect of delivery of more sodium under these circumstances is difficult to predict. Although distal sodium-hydrogen ion exchange might have been accelerated, especially in two experiments in which basal sodium excretion was low (e.g., Subject D, Table I), this appears a not entirely satisfactory explanation for the observations in the other studies in which 
TABLE II

Effect of water diuresis on urine $p H$ and renal acid excretion

\begin{tabular}{|c|c|c|c|c|c|c|}
\hline \multirow[t]{3}{*}{ Experiment no. } & \multicolumn{2}{|c|}{$\mathrm{pH}$} & \multicolumn{2}{|c|}{$\mathrm{UNH}_{4} \mathrm{~V} \ddagger$} & \multicolumn{2}{|c|}{ UTAV $\ddagger$} \\
\hline & \multirow[b]{2}{*}{ Control* } & \multirow[b]{2}{*}{ Diuretic $\dagger$} & \multicolumn{2}{|c|}{$\mu E q / \min$} & \multicolumn{2}{|c|}{$\mu E q / \min$} \\
\hline & & & Control & Diuretic & Control & Diuretic \\
\hline $\begin{array}{l}1 \\
2 \\
3 \\
4\end{array}$ & $\begin{array}{l}5.0 \\
5.2 \\
6.0 \\
6.5\end{array}$ & $\begin{array}{l}6.3 \\
6.5 \\
6.6 \\
6.9\end{array}$ & $\begin{array}{l}31 \\
21 \\
17 \\
14\end{array}$ & $\begin{array}{l}27 \\
19 \\
24 \\
23\end{array}$ & $\begin{array}{r}11 \\
28 \\
5.0 \\
5.2\end{array}$ & $\begin{array}{c}6.7 \\
29 \\
4.6 \\
5.1\end{array}$ \\
\hline \multicolumn{7}{|l|}{ Recumbent } \\
\hline $\begin{array}{l}5 \\
6 \\
7 \\
8\end{array}$ & $\begin{array}{l}7.1 \\
7.2 \\
6.8 \\
7.2\end{array}$ & $\begin{array}{l}7.2 \\
7.0 \\
6.8 \\
6.8\end{array}$ & $\begin{array}{c}18 \\
12 \\
19 \\
4.8\end{array}$ & $\begin{array}{l}14 \\
12 \\
18 \\
21\end{array}$ & $\begin{array}{l}6.5 \\
2.3 \\
5.9 \\
1.1\end{array}$ & $\begin{array}{c}9.8 \\
3.6 \\
11 \\
8.7\end{array}$ \\
\hline
\end{tabular}

* Control: average of 2 to 3 control periods.

† Diuretic: average of 2 to 3 periods at height of diuresis.

$\ddagger \mathrm{U}_{\mathrm{NH}_{4}} \mathrm{~V}=$ urine ammonium excretion; $\mathrm{U}_{\mathrm{TA}} \mathrm{V}=$ urine titratable acid excretion.

there was already a natriuresis before solute loading (e.g., Subject E, Table I).

The hypothesis that acid formed in proximal segments of the nephron reaches the final urine may provide an explanation for a significant part of the observed changes, but requires further comment. First, it must be assumed that acidification occurs in the human proximal tubule and that the process continues during recumbency. The fact that the $\mathrm{pH}$ of proximal tubular fluid has been lower than that of plasma under all conditions that have been studied thus far in the mammalian kidney supports this assumption. A further implication of the hypothesis would be that during the alkaluria of recumbency, acid formed in the proximal tubule is dissipated ${ }^{4}$ in the distal nephron. In this view, the capacity of the distal nephron to form an alkaline urine was exceeded with increased delivery of proximal fluid during solute diuresis. In several instances, however, the urine $\mathrm{pH}$ values at the height of solute diuresis were lower than those reported for the proximal tubule of the rat undergoing mannitol diuresis (21-23). It therefore seems likely that, in addition to the delivery of acid from the proximal tubule, the sodium-hydrogen ion exchange mechanism in the distal nephron played some role in the observed increase in acid excretion. Al-

\footnotetext{
${ }^{4}$ Gottschalk (26) has observed in the hamster that the $\mathrm{pH}$ of fluid in Henle's loop is more alkaline than in the proximal tubule and has suggested that under some experimental conditions, acid formed in the proximal tubule may be dissipated in the medulla.
}

though the relative importance of the two mechanisms cannot be appraised from the present data, the possibility that proximal segments of the nephron contribute to renal acid excretion should be taken into account in physiological and pathological conditions associated with high levels of solute excretion.

\section{SUMMARY}

The effects of acute increases in the excretion of either solute or water on renal acid excretion were studied in hydropenic subjects. Water diuresis had no consistent effect on acid excretion in subjects in the recumbent position; in subjects in the upright position elaborating an acid urine, a rise in urine $\mathrm{pH}$ resulted without appreciable change in over-all acid excretion.

Diuresis induced by nonelectrolyte solutes (mannitol or urea) in the presence of antidiuretic hormone caused a fall in urine $\mathrm{pH}$ and significant increases in ammonium and titratable acid excretion in recumbent subjects. These effects could not be attributed to changes in posture, systemic acid-base equilibrium, or glomerular filtration rate.

In order to account for the aciduria that occurred with solute diuresis under the present experimental conditions, it is postulated that, in addition to acceleration of the distal sodium-hydrogen ion exchange mechanism, ammonium and titratable acid formed in proximal segments of the nephron contributed to the acid content of the final urine. 


\section{ACKNOWLEDGMENT}

The authors are grateful to Miss Joyce Hornung for technical assistance.

\section{REFERENCES}

1. Schwartz, W. B., R. L. Jenson, and A. S. Relman Acidification of the urine and increased ammonium excretion without change in acid-base equilibrium: sodium reabsorption as a stimulus to the acidifying process. J. clin. Invest. 1955, 34, 673.

2. Epstein, F. H., C. R. Kleeman, E. Lamdin, and M. E. Rubini. Studies on the antidiuresis of quite standing; observations upon electrolyte and acid-base excretion during sulfate diuresis. J. clin. Invest. 1956, 35, 308.

3. Berliner, R. W., T. J. Kennedy, Jr., and J. Orloff. Relationship between acidification of the urine and potassium metabolism. Effect of carbonic anhydrase inhibition on potassium excretion. Amer. J. Med. 1951, 11, 274.

4. Lauson, H. D., and D. D. Thompson. Effects in dogs of decrease in glomerular filtration rate on cation excretion during intravenous administration of unreabsorbable anions. Amer. J. Physiol. 1958, 192, 198.

5. Bank, N., and W. B. Schwartz. The influence of anion penetrating ability on urinary acidification and the excretion of titratable acid. J. clin. Invest. 1960, 39, 1516.

6. Sullivan, L. P., W. S. Wilde, and R. L. Malvin. Renal transport sites for $\mathrm{K}, \mathrm{H}$ and $\mathrm{NH}_{3}$. Effect of impermeant anions on their transport. Amer. J. Physiol. 1960, 198, 244.

7. Barclay, J. A., W. T. Cooke, R. A. Kenney, and M. E. Nutt. The effects of water diuresis and exercise on the volume and composition of the urine. Amer. J. Physiol. 1947, 148, 327.

8. Mudge, G. H., J. Foulks, and A. Gilman. Effect of urea diuresis on renal excretion of electrolytes. Amer. J. Physiol. 1949, 158, 218.

9. Urbach, J. R., M. D. Phelps, W. S. Steiger, and S. Bellet. Effect of water diuresis on renal excretion of certain urinary solutes in normal man. J. appl. Physiol. 1953, 6, 243.

10. Beck, R. N. Osmotic diuresis and the base sparing function of the kidney. Clin. Sci. 1958, 17, 37.

11. Nutbourne, D. M., and H. E. de Wardener. The effect of a water diuresis on the urinary excretion of hydrogen ions in man. Clin. Sci. 1961, 20, 63.
12. Goldring, W., and H. Chasis. Hypertension and Hypertensive Disease. New York, Commonwealth Fund, 1944, p. 195.

13. Brod, J., and J. H. Sirota. The renal clearance of endogenous "creatinine" in man. J. clin. Invest. 1948, 27, 645.

14. Sanderson, P. H. Potentiometric determination of chloride in biological fluids. Biochem. J. 1952, 52, 502.

15. Seligson, D., and H. Seligson. A microdiffusion method for the determination of nitrogen liberated as ammonia. J. Lab. clin. Med. 1951, 38, 324.

16. Van Slyke, D. D., and J. M. Neill. The determination of gases in blood and other solutions by vacuum extraction and manometric measurement. I. J. biol. Chem. 1924, 61, 523.

17. Thomas, S. Some effects of change of posture on water and electrolyte excretion by the human kidney. J. Physiol. 1957, 139, 337.

18. Hendrix, B. M., and J. P. Sanders. The effect of injections of sodium phosphates and sodium hippurate upon the excretion of acid and ammonia by the kidney. J. biol. Chem. 1923, 58, 503.

19. Orloff, J., and R. W. Berliner. The mechanism of the excretion of ammonia in the dog. J. clin. Invest. 1956, 35, 223.

20. Eggleton, M. G. Some factors affecting the acidity of urine in man. J. Physiol. 1947, 106, 456.

21. Gottschalk, C. W., W. E. Lassiter, and M. Mylle. Localization of urine acidification in the mammalian kidney. Amer. J. Physiol. 1960, 198, 581.

22. Bank, N. Relationship between electrical and hydrogen ion gradients across rat proximal tubule. Amer. J. Physiol. 1962, 203, 577.

23. Litchfield, J. B., and P. A. Bott. Micropuncture study of renal excretion of water, $\mathrm{K}, \mathrm{Na}$, and $\mathrm{Cl}$ in the rat. Amer. J. Physiol. 1962, 203, 667.

24. Glabman, S., and G. Giebisch. Personal communication.

25. Bloomer, H. A., F. C. Rector, Jr., and D. W. Seldin. Micropuncture study of the contributions of proximal convolution, distal convolution and collecting duct to titratable acid formation. Clin. Res. 1963, 11, 67.

26. Gottschalk, C. W. Renal tubular function: lessons from micropuncture. Harvey Lecture, December 20, 1962. To be published in The Harvey Lectures, 1962-1963, series 58. 